\title{
Planning of flood defence management and rehabilitation of the natural habitat in the downstream part of the river Tiber
}

\author{
L. de Santoli, D. Astiaso Garcia \& A. C. Violante \\ Centro Interdipartimentale per il Territorio, l'Edilizia, \\ il Restauro e l'Architettura (CITERA), Rome University "Sapienza", \\ Italy
}

\begin{abstract}
The aim of this project is to single out sections along the final tract of the river Tiber, from the Castel Giubileo breakwater to the estuary, including main feeders, in need of flood defence management interventions and environmental redevelopment. After running through the city of Rome, the Tiber flows downstream through a territory where urban needs coexist with cultural heritage and a particularly riparian ecosystem. For this project it was therefore decided to use bioengineering techniques in order to bring about the minimum impact on both the environment and the landscape. These can be used to minimise streambank erosion, to prevent flood events and for streambed shaping. Furthermore, they are a valid tool for the restoration of the ecological integrity of the riparian ecosystems and wetlands. The next step was to pinpoint critical zones in need of a new embankment system for the security of Rome's suburban districts nearby. The final product was the development of a cartographic support of the study area, elaborated with GIS software "Arc Gis 9.1", listing all the planned works by area as well as the most suitable techniques in accordance with the entity of the problem and the constraints of that zone. In addition, we drew up a technical data sheet for each kind of intervention, pinpointing all the locations along the Tiber where each intervention is planned. The shapefiles and technical data sheets are useful instruments for the requalification of what remains one of the most beautiful and vulnerable sections of the river Tiber.

Keywords: flood defence, bioengineering techniques, vegetated rock wall, coir fiber roll, flood retention basin, sill, rehabilitation of natural habitats.
\end{abstract}




\section{Introduction}

The correct management of river systems entails the preservation of the delicate ecosystems and particular landscape features that characterise such areas without hampering the correct use of the resources and a rational fruition of the surrounding areas.

Fluvial environments that are within an urban context in particular need to be managed in such a way that the preservation of the natural and fluvial areas does not interfere with the many requisites dictated by the living standards of typical urban areas.

One must also bear in mind that the Italian territory is blessed with a unique historical heritage - the fruit of thousands of years of subsequent civilisations that is protected by a number of national and regional laws designed to preserve this priceless treasure. Among these laws there are those that forbid construction of works that would lower the effective value of certain archaeological and landscape areas.

The main objective of our study was therefore to examine the possibility of implementing works in anthropised river environments, considering environmental, archaeological and landscaping constraints in an urban context with its several needs [1].

In an effort to narrow the work down to a specific area, we found that a particularly suitable section would be the final tract of the river Tiber, precisely the section running from the Castel Giubileo dam (where the river crosses under the northern section of the Grande Raccordo Anulare Rome ring road) to the mouth.

This section of the river in fact presents a number of unique characteristics: it runs through the city of Rome and the final section crosses an area of typical river habitats - some of which are still intact; built up areas and areas of interest in terms of the evolution of the city of Rome through the millennia.

The study area included also the last section of the river Aniene, from Tivoli to its affluence into the Tiber, as well as the thirteen main tributaries of the Tiber that form "natural corridors" running through areas with heavy anthropisation exactly like the area in question.

Both for the Tiber and the Aniene, as well as for the other tributary rivers, the study area included the rivers themselves and the entire 'fluvial corridor' comprising the areas of land in some way related to the river ecosystem (fig. 1).

Within the study area we then highlighted the areas within the fluvial corridors of the Tiber, the Aniene and the 13 tributary rivers that were in short term need of riverbank erosion containment, new embankment systems, environmental requalification, flood defence works, riverbed modelling, installation of structures for collecting and conveying superficial waters, and the creation of wetlands.

Where possible, we preferred to opt for solutions that entailed the use of bioengineering techniques in that they permit solving situations of hydrogeological disruption whilst causing low environmental impact and sometimes a degree of territorial requalification [2]. These techniques are a valid operative 
tool for attaining a territorial management that is environmentally compatible within a framework of safeguarding ecosystems and increasing biodiversity. Within the context of works in fluvial environments, these techniques consent the achievement of a number of goals such as consolidating banks by combining live elements such as plants with inanimate materials such as wood, stone, steel netting, etc. The combination of these materials retains the permeability of the structure in terms of matter and energy exchange between the bank and the river. All this allows the development of new ecosystemic units, which is one of the goals of natural engineering works. As well as increasing biodiversity in a highly anthropised area such as that of the city of Rome, where human activity has largely destroyed the local plant community, these ecosystemic units provide an "ecological corridors" that connects the various ecosystems of the territory as a whole.

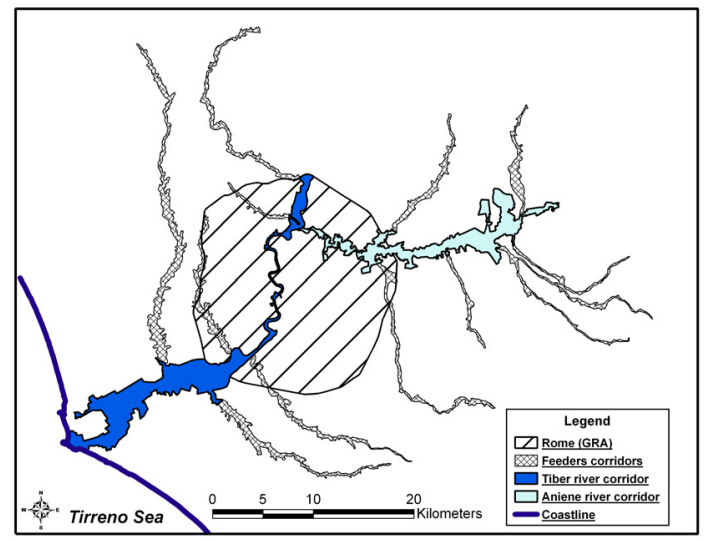

Figure 1: $\quad$ Study area.

Bioengineering techniques are spreading also to the central and southern regions of the Italian peninsula [3-7], following their application in the country's Alpine regions. The application of these methods needs to be preceded by an analysis of the ecosystem in the area in question as well as in a large surrounding area, so as to have a full picture of the variety of local ecosystems. This enables a correct choice of species to be used in the project.

Bioengineering techniques were planned for the areas where work was needed, trying to avoid cement interventions that create an impermeable barrier to life and destroy the interconnection between living organisms (plants, animals) and inanimate materials (geological substrata, water table etc) within the ecosystem.

Given the prevalently urban context of the final section of the Tiber, where there are a number of limitations to such works, only certain forms of intervention were realistically feasible. For example, in heavily built up areas near riverbanks there is not normally enough space to implement works that entail the reduction of the speed of the current or of the stream cross-section. 


\section{Planned works}

The GIS (Geographic Information System) "Arc Gis 9.1" software enabled us to draw up a detailed map of the study area in a series of 1:10,000 scale boards pinpointing all the areas where works were due to be carried out along the corridor of the Tiber, the Aniene and the 13 affluent rivers. Working in GIS also consented the compilation of an electronic database where each planned work was accompanied by tables containing information concerning the problem, the type of proposed solution, a description of the materials that would be used, the legislative limitations imposed on the area and a cost estimate according to the guidelines published in 2006 by the Italian Ministry of the Environment and the Italian Ministry of Economy [8].

All this information was also gathered in technical sheets where each kind of intervention was accompanied by application fields, a list of the materials that could be used and the location of the planned intervention.

\subsection{Anti-erosion works}

Over the years, erosion along the banks of the river Tiber has increased. This is due chiefly to two causes: the erection of artificial banks and containing walls in the urban section of the river, which has caused the widening of the low and high water level bed, and downstream where the opposite is the case, from spurs that have caused the riverbed to narrow. The second cause is chiefly attributable to the drop in silting due to the subtraction of considerable amount of matters from the river bed, utilized for the setting up of roads and railways. At Ripetta, in particular, there has been a 30-fold drastic drop in silting since 1935 to the present day.

The section of the river that runs from Castel Giubileo to the estuary features a number of areas that are particularly vulnerable to erosion. It is possible to stop erosion in these sections by the construction of "vegetated rock walls". These structures are carried out by placing large boulders in a parallel line with the current, with a sloping side towards the river that gives the riverbed a trapeze shape. Willows or other species of tree with similar biotechnical capacities are then planted between the boulders to offer stability to the bank structure once they have taken root. These structures must have deep foundations to ensure that they are not dislodged at the base by the strength of the current.

The section of the river Tiber at "Tor di Valle" is an explanatory example of this kind of intervention (fig. 2).

In view of plans to create a nature reserve to the right hand side of the river in the section near Ponte Milvio, a number of works aimed at preventing erosive phenomena have been planned.

As well as the environmental restrictions that would come into force with the institution of the nature reserve, the area is already protected by a number of historical and archaeological restrictions for buildings such as the Milvio Bridge and the late- $19^{\text {th }}$ century Flaminio Bridge, not to mention the archaeological remains that are still underground. It is therefore necessary to work with 
technologies that in no way interfere with the environmental, archaeological and historical context of the area. We therefore advise coir fiber rolls in combination with hydroseeding of varieties of grass (e.g. Enula cepittoni, Inula viscosa) and autochthonous shrubs (common elder, Sambucus nigra) and trees (common willow, Salix alba) (fig. 3). Coir fiber rolls provide an immediate protection to the surface of the riverbank and adhere to the substrata even where it presents gaps or protrusions.

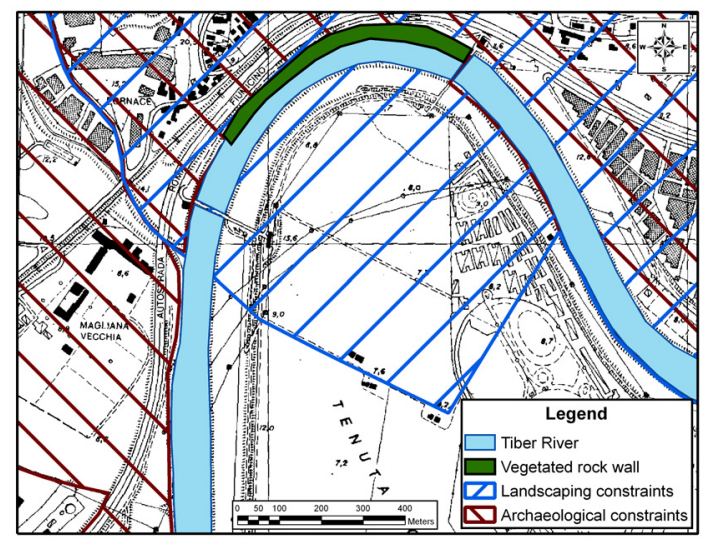

Figure 2: $\quad$ Vegetated rock wall as foreseen in the South of Rome.

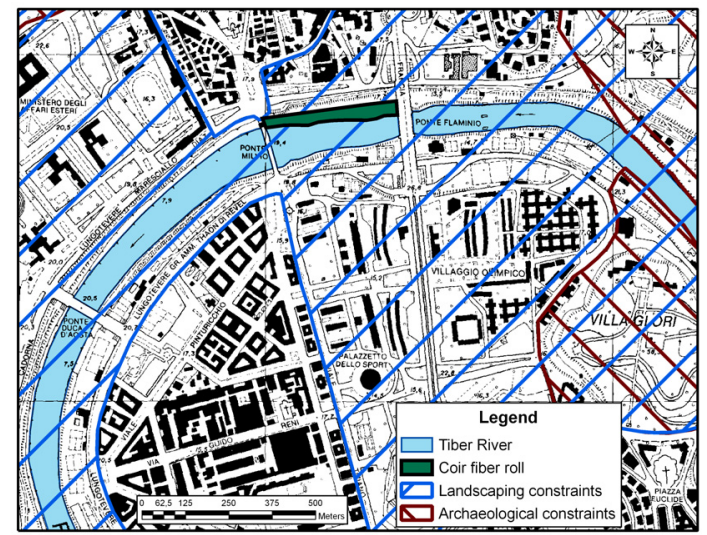

Figure 3: Coir fiber roll as foreseen in the Ponte Milvio Area of Rome.

\subsection{Flood protection works}

Given the vast area at risk of flooding along the fluvial corridor of the river Tiber, a capillary system of embankments has been built particularly in the section that runs through the city. We have planned works directed mainly towards the upkeep of this system, bearing in mind specific local hydraulic 
necessities. It would appear that new works to secure embankments are necessary to safeguard the many built up areas along the suburban and extraurban sections of the Tiber and the Aniene.

The embankments should guarantee full hydraulic functionality. It is therefore advisable to follow courses that are compatible with the hydraulic needs of the river (avoid sharp variations in the course that would be vulnerable to the erosive action of the current) whilst respecting the environmental needs that normally advise against the use of sharp geometrical lines, as well as plan an adequate planting of the area to ensure that the work blends in imperceptibly with the fluvial environment.

Two kinds of embankment would appear most suitable: dirt levees and flood walls.

Being trapezoid in structure, dirt levees need more space than flood walls but have the advantage of offering a greater integration with the natural landscape. They are therefore particularly suitable for areas with landscape or environmental restrictions such as nature reserves (fig. 4). Flood walls entail a greater impact on fluvial habitats and landscape, and are usually necessary where there is not enough space to build dirt levees.

We have pinpointed a situation of this kind along a section of the river Aniene that runs within the Nature Reserve "Valle dell'Aniene", instituted by regional legislation 29/97 (fig. 5).

In areas where urban expansion is most intense it would be possible to build flood retention basins in order to temporarily contain considerable quantities of water. The contained water is returned once the hydrometric conditions are past danger point. In terms of impact on the environment, flood retention basins have a low impact on the surrounding landscape [9]. Particularly for basins that straddle water courses, and are therefore in part frequently flooded, it is possible to create nature reserves.

Even retention of small quantities of water in fact enables the creation of humid habitats that can be used by birds and fauna, and consents the development of vegetation that is able to survive periodical flooding in areas that are most exposed to this phenomenon.

We have planned a flood retention basin in order to safeguard the urban area of San Basilio, near the "Fosso di Pratolungo" tributary of the river Aniene (fig. 6).

\subsection{River bed modelling works}

This kind of intervention are performed when it is necessary to remove riverbed sediments and consists of cutting down trees and removing solid waste, as well as widening the channel cross-section in order to increase maximum discharge.

We have pinpointed the need for such works at some small tributary of Tiber or Aniene river.

When working on smaller rivers it is advisable - where possible and after an inspection of the kind of riverbed - to create small sills in wood or stone. 


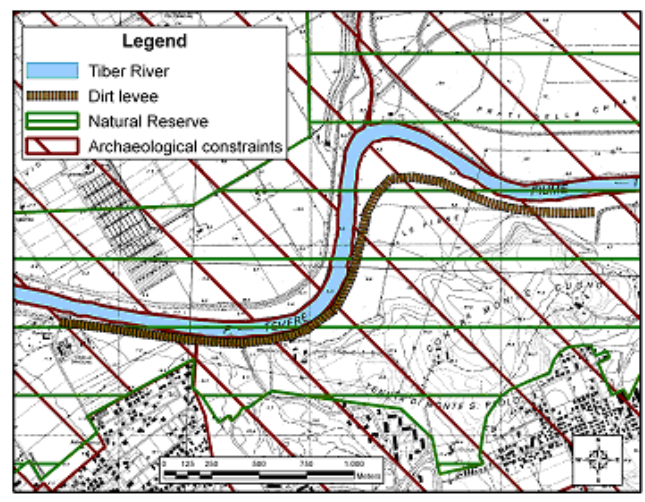

Figure 4: Dirt levee as foreseen between the city of Rome and the mouth of Tiber river.

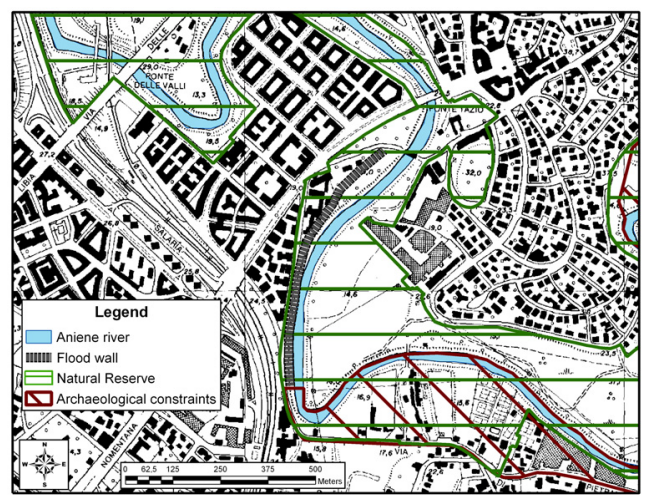

Figure 5: Flood wall as foreseen in an urban zone of the Aniene river.

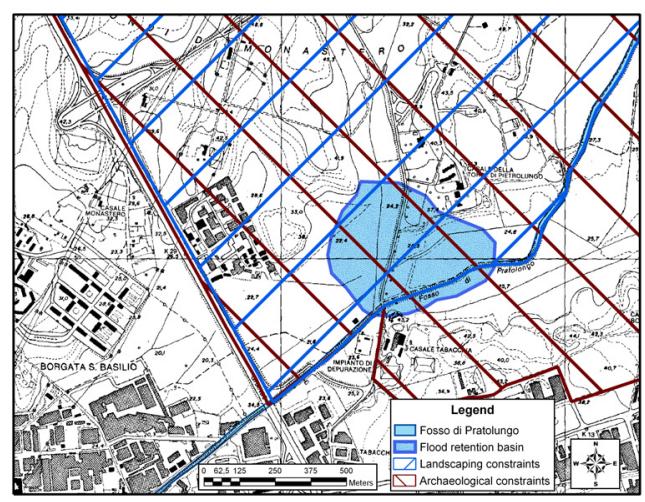

Figure 6: Flood retention basin for the safeguarding of the San Basilio area. 
Sills are low transverse structures built in order to prevent bed erosion or raise the upstream water level. In a river course with erosive tendencies sills simply fix altimetry at a local level so that the level of the riverbed does not drop. In the event of erosion taking place upstream this will therefore reduce sloping.

Within the study area we saw that sills should be put in place along Fosso di Crescenza and Fosso dell'Acquatraversa, at Due Ponti, near where they merge with the Tiber (fig. 7).

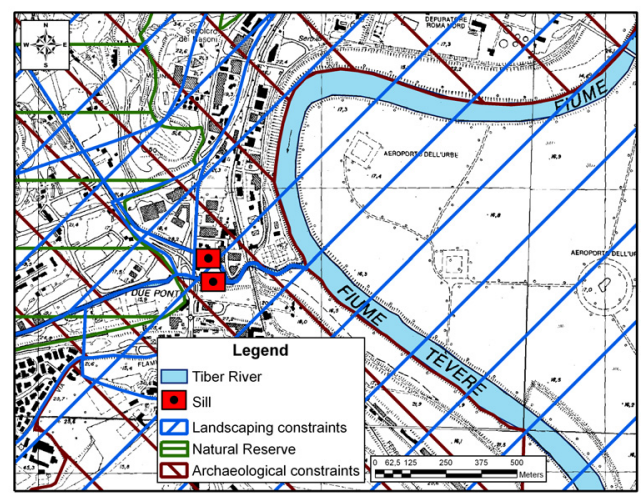

Figure 7: Sills planned in a feeder of the Tiber river.

\subsection{Rehabilitation of natural habitats}

Management and intervention policies regarding rivers and lakes in Italy have not always been respectful of the natural habitats they support. When choosing between one kind of intervention and another for flood protection of a certain area the main priority has frequently been to safeguard that area without paying much attention to carrying out a complete and exhaustive analysis of the surrounding environment.

Among the necessary environmental requalification works along the stretch of the Tiber that runs between Castel Giubileo and its mouth, we considered the possibility of focussing on restoring the vegetation, fauna and landscape upstream near Ponte Milvio (fig. 3). This would entail eliminating the allochthonous species present and favour the growth of trees and shrubs that are ecologically coherent with the local riverbank habitat, whilst maintaining the existing clearings. The restoration of the vegetation should also favour the development of the birdlife connected with it, in terms of the diverse habitats present and trophic availability.

Rehabilitation of natural habitats and consolidation works should also be considered for the damp area at "Drizzagno di Spinaceto" (SIN, Sito d'Interesse Nazionale, part of the Bioitaly project) (fig. 8).

Damp areas are used mainly as a means to recover the self-purifying capacity of ecosystems connected with the surface water system. They are in fact able to reduce a variety of polluting agents such as suspended solids, nitrogen and phosphorous composites, bacteria and metals etc., through chemical, physical 
and biological processes [10]. The efficiency of the purifying process depends on the amount of time water stays within the damp area, the distribution of vegetation, hydraulic efficiency and light.

When designing a damp area it is essential to carry out a meticulous evaluation of weather and geographical conditions, pedology, geology, stratum behaviour, hydrology, water quality and impact on the environment.

Wetlands are frequently considered one of the most productive biological systems on account of their ability to export large quantities of organic matter. Primary productivity is highest in damp areas with a laminar water flow, since quick water flow tends on the contrary to discourage plant growth.

Ecosystems of damp areas include a variety of autotrophic (primary producers, such as plants etc.) and heterotrophic (consumers, such as microbes and animals) components. Damp areas are appreciated also for their nonproductive values (landscape, recreational, educational, research). They must therefore be equipped with informative panels describing the nature itineraries, as well as the species of animals and plants present. There could also be an information centre containing a museum and materials for educational activities. Specific structures of this kind need to be planned to encourage fruition by walkers, cyclists, birdwatchers and joggers.

As well as offering the satisfaction of having a quality nature reserve a short distance from the city, these social uses can make an important contribution towards earning public favour for rehabilitation of natural habitats, consolidation and protection of the damp area.

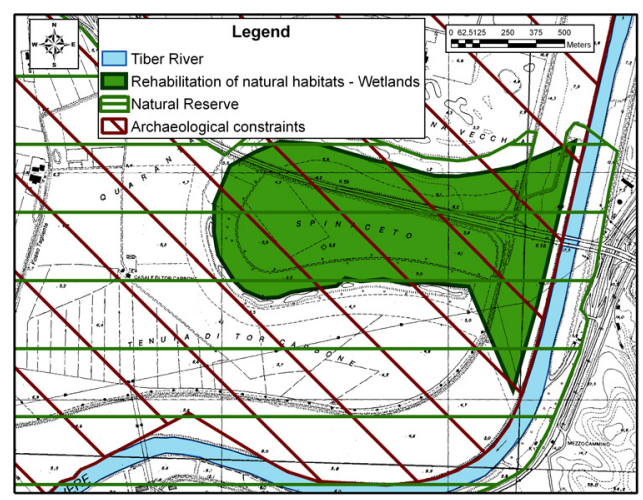

Figure 8: Rehabilitation of natural habitats in the South of Rome.

\section{Conclusions}

The examples listed above are just a partial illustration of the final product, which includes also an electronic cartography of the city of Rome and environs, highlighting areas of intervention in fluvial habitats and possible solutions for each single context. 
Results obtained so far show that bioengineering techniques can be applied well also to urban environments, particularly to solve problems connected with rivers in areas where it is important to reduce environmental and landscape impact to a minimum. As an additional support, we have compiled a series of information cards listing costs, materials and impact of each planned river intervention.

As a whole, this information provides a useful tool for obtaining an overall view of the fluvial problems of the Italian capital, along with valid solutions for planning interventions that guarantee continued improvement for the future territorial management of the city of Rome.

\section{References}

[1] De Santoli L., Monaco A., Cinquepalmi F. Guidelines for the choosing of river interventions considering environmental, archaeological and landscaping constraints. Fourth International Conference on River Basin Management. WIT press, 2007.

[2] Preti F. Sistemazioni idraulico-forestali e ingegneria naturalistica per la difesa del territorio. Sintesi dell'intervento al convegno - L'ingegneria naturalistica in ambiente mediterraneo - Pisa, 22 aprile 2004.

[3] Regione Lazio, Assessorato per l'Ambiente, Dipartimento Ambientale e Protezione Civile, Roma. Manuale di Ingegneria Naturalistica applicabile al settore idraulico. 2002.

[4] Regione Molise. Studio del rischio idrogeologico nella regione. Sezione B: Rischio idraulico. Definizione degli interventi. Maggio 2001.

[5] Regione Toscana. Principi e linee guida per l'ingegneria naturalistica. 1-Processi territoriali e criteri metodologici. 2- Schede tecniche. Volume I- II, 2000.

[6] WWF; Regione Marche. Manuale di metodologie e tecniche a basso impatto in materia di difesa del suolo. Studio di nuove metodologie ambientali in materia di difesa del suolo e miglioramento ambientale.

[7] Provincia di Terni; AUR (Agenzia Umbra Ricerche). Manuale tecnico di ingegneria naturalistica della provincia di Terni. Maggio 2003.

[8] Ministero dell'Ambiente e della Tutela del Territorio, Ministero dell'Economia e delle Finanze, PODIS (Progetto Operativo Difesa del Suolo). Linee guida per capitolati speciali per interventi di ingegneria naturalistica. Edizione 2006.

[9] Da Deppo L. Casse d'espansione fluviali. Aspetti costruttivi. La difesa idraulica dei territori fortemente antropizzati. Editoriale BIOS. 1997

[10] ANPA (Agenzia Nazionale Protezione Ambiente). Linee guida per la ricostruzione di aree umide per il trattamento di acque superficiali. 2002. 